\title{
A Study on the Influencing Factors and Countermeasures in College English Listening Teaching
}

\section{Tong Yinping}

International Education College, Xi'an Peihua University, Chang'an Campus, Xi'an, Shaanxi, China

524476009@qq.com

Keywords: College English Listening Teaching; English Listening; Listening Ability

\begin{abstract}
The cultivation of listening ability has always been being one of the difficult points in college English teaching. Having a good command of listening ability is the key for effective communications. However, the current situation of college English listening teaching is far from our satisfaction. There are some factors affecting the improvement of college students' English listening ability. The author discusses three factors which are the traditional teaching mode of college English listening, Students' weak foundation of English language and some psychological barriers in the process of listening. Then some countermeasures against the inefficiency of college English listening teaching was put forwards in order to facilitate listening teaching.
\end{abstract}

\section{Introduction}

In common cases, when people talk about the five aspects of English learning, listening, speaking, reading, writing and translating, they always put listening the first one. So it can be concluded that listening ability is of great significance in English learning and teaching. In the "College English Curriculum Requirements" (2007) made by the ministry of education, it is explicitly pointed out that the teaching objectives of college English are to cultivate students' comprehensive ability, especially listening and speaking skills, and to make them able to communicate effectively in English in their future study, work and social communication. With the development of global economy, students are provided with more and more opportunities to communicate with others in English in their work and study. Therefore, It is vitally important to improve students' listening and speaking ability. In 2006, College English Test Band 4 and Band 6 were made a reform, in which the proportion of listening comprehension was increased from $20 \%$ to $35 \%$, showing the importance of listening teaching. Listening, as the input of language, is the first step of interpersonal communication, which affects the improvement of language communication ability. Therefore, the cultivation of listening ability should be given the priority in college English teaching. However, for a long period, the English listening ability of Chinese college students is generally low, which is an indisputable fact. Listening teaching has always been one of the difficulties in college English teaching. Actually, listening is what students are most afraid of and they often complain that it is really difficult to improve their listening ability. Sometimes, even they listen to the materials again and again, they still cannot get it. Thus, how to do a good listening class and how to quickly improve students' listening ability are especially urgent and crucial. This paper will discuss some factors that affect the improvement of students' listening ability and put forward some possible solutions.

\section{Factors Affecting the Improvement of College Students' English Listening Ability}

College students' listening ability is generally low, among which there are many influencing factors. This paper mainly discusses the following aspects:

\subsection{The Traditional Teaching Mode of College English Listening is Monotonous.}

In the traditional college English teaching, teachers, as the main body of the class, are busy with the imparting of language knowledge and neglects the cultivation and training of students' language 
application ability, which results in students' being unable to communicate effectively in English, that is, they cannot understand or speak. The traditional teaching method of college English listening is too monotonous and boring, many teachers usually teach in the way of explaining words, playing recordings to students and answering questions together. The class atmosphere is dull and tedious, and students will easily feel bored and drowsy. In order to complete the teaching task, teachers spend most of the class time on the training of listening. Students tend to be tired and distracted easily with their eyes and ears and it is difficult for them to focus on the listening materials for a long time. Some students even play cell phones or sleep as soon as class begins. The main reason is that teachers play a dominant role in listening class and students are merely passive receivers. Students are not active enough in learning and excessively rely on teachers and class. Due to the heavy teaching tasks and teacher-centered teaching mode, students are in a state of passive acceptance for a long time, lack of initiative in learning and develop the habit of relying on teachers. After class, they scarcely do listening exercises and their listening ability cannot be improved.

\subsection{Students do not have a Solid Foundation of English Language.}

The process of listening comprehension is one in which people use all kinds of background knowledge and skills to understand the information. If students do not have a good command of pronunciation, vocabulary and cultural knowledge, they cannot understand the listening materials well inevitably.

First of all, students' knowledge of phonetics is weak. Most students did not go through a systematic learning and training of phonetics in middle school, but spent most of their time in learning grammar, vocabulary, etc. They do not have a good understanding of rules about liaison, stress, blasting and weak reading in English, which affected their understanding of listening materials. Some students come from regions where people have a strong accent and their pronunciations are not accurate, therefore they cannot distinguish two or more words which have very similar pronunciations. What is worse, some middle school English teachers cannot speak standard or fluent English, so that students cannot master correct pronunciation and intonation in the initial stage, which all become obstacles for students to understand the listening materials correctly. In addition, the English textbooks in elementary and secondary schools are mostly with British English pronunciation, which brings about difficulties for Chinese students to understand American English after they enter universities since a lot of college textbooks are of American English pronunciation.

Secondly, students do not acquire enough knowledge of vocabulary. In some cases, even if they can hear the words clearly, they still do not know the meaning of the words. In addition, there are many polysemic words in English which have multiple meanings and different usages. In different contexts, words have different meanings or usages. However, students only master one or two of the meanings or usages, which leads to the misunderstanding of the whole sentences. For instance, students know that the word "contain" has the meaning of "include", but they may not know the word has the meanings of "keep something under control" and "prevent something harmful from spreading or getting worse". So students are unable to understand the sentences "She was unable to contain her excitement" or "Government forces have failed to contain the rebellion".

Thirdly, students do not have a good understanding of western cultures and differences between different cultures, which causes the consequence that they cannot understand the meanings of some sentences or utterances in specific contexts. Anderson and Lynch have pointed out that the lack of social culture, historical facts and background knowledge of the target language will become a barrier in listening comprehension, because language is actually used to convey culture. (Anderson and Lynch, 1988). As a matter of fact, Learning a language is learning a culture, the language being the carrier of the culture. Lack of understandings of the social and cultural background knowledge will unavoidably lead to misunderstandings in listening. For example, students may not know the meaning of "it rains cats and dogs" which causes their confusion in listening.

\subsection{Psychological Barriers}

For most of the first-year students, listening is particularly hard because they haven't got any 
special training in this aspect in middle school. Many students are in a state of nervousness, anxiety and fear while listening to English after attending university, which is caused by a variety of factors, including spontaneous psychological worries, unfamiliar pronunciation, fast speed, texts of long length, vague cultural background knowledge, a small amount of vocabularies and less listening practice. The tension has already led the students to be trapped. If they encounter difficult listening materials, they will not be willing to listen any longer because of fear. As a result, their minds will be blank and they will get nothing from what they are listening to. Nervousness or inattentiveness during listening practice will influence the overall effect of comprehension, which will cause a sense of frustration to students. Over time, students will lose their enthusiasm and confidence in English listening.

\section{The Countermeasures against the Inefficiency of College English Listening Teaching}

In view of the above discussed factors, the author proposed the following countermeasures based on years of teaching experience:

\subsection{Adopt Flexible and Diverse Teaching Methods}

Listening and speaking are two basic skills that cannot be separated in the process of learning a foreign language. In order to improve listening ability and acquire a language, it is better to combine listening with speaking than simply conduct the training of listening. Through the combination of listening and speaking, students can not only improve their listening comprehension, but also improve their oral expression. The advanced auxiliary teaching mediums such as multimedia and network can create a vivid and lively bilingual context for students. In listening teaching, teachers should give full play to these modern teaching mediums, implement foreign language teaching in an overall way. The combination of images, pictures and sounds can greatly help increase students' interests in learning, enliven the class atmosphere and achieve good teaching results. With the promotion of modern teaching mediums, teachers and students can get various listening materials from different sources. But teachers should select appropriate materials according to teaching requirements and students' actual English level. Besides being understandable, these materials should be interesting and relevant to students' lives. For instance, the original English movie is a good choice. Through the combination of sounds, images and words, it reproduces the vivid and real language environment, which has become an effective teaching method in English teaching. Moreover, teachers should develop more second-class activities, introduce some websites, radios, APPs to practice listening and increase extensively listening materials proper to students, including biographies, anecdotes, customs, cultures, classic songs, etc. so as to greatly enrich students' knowledge about English countries and motivate them in learning English.

\subsection{Strengthen Students' Basic Language Knowledge}

Possessing a solid foundation of English is the basis for students to possess a good listening ability. However, universities and even middle schools have weakened the teaching of basic English knowledge in recent years, which is also one of the reasons why students do not have a good command of English.

In daily teaching, teachers should attach great importance to students' pronunciation, correct the mistakes or errors which appear frequently in students' pronunciation, strengthen students' ability to distinguish sounds and help students to gradually master the special forms of liaison, weak reading, loss of blasting, etc.. Teachers should encourage students to listen to native English as much as possible, help students download some news in VOA and BBC news programs which are suitable for them, and let students watch original English movies and listen to English songs. Through these channels, students can get access to a large number of original English, get familiar with the standard English pronunciation and experience authentic English, rather than the English of several Chinese English teachers. Next, teachers should strengthen the teaching of vocabulary and grammar, and encourage students to read English newspapers, magazines and novels so as to enrich 
vocabularies and master the special usages of some common words. In the teaching, teachers should also review and summarize some specific grammar knowledge intentionally, such as emphatic sentences, inverted sentences and subjunctive mood. It is difficult for students to recognize these special sentences without specific training in them because time is very limited in the process of listening. Therefore, teachers should train students be sensitive to these grammatically special sentences in doing listening exercises. What's more, in the process of teaching, teachers should also introduce British and American cultures to students in a conscious and planned way in order to let students learn as much as possible about the customs, practices and living habits of English-speaking countries. For instance, teachers can recommend some books, movies and operas that introduce western cultures to students. In this way, some obstacles resulted from cultural differences can be eliminated and thereby students' listening comprehension is likely to have a big improvement.

\subsection{Form a Good State of Mind and Cultivate Good Listening Habits}

A striking feature of listening is "transience," which causes listeners' great anxiety in the course of listening. When the sounds come into ears continuously, students will feel panicky and cannot focus on listening, thus affecting the understanding of the listening materials. In view of the psychological factors of students, teachers should help students to boost their confidence in listening and encourage them to overcome difficulties in listening. First of all, teachers should take the order of "from the easy to the difficult" when doing listening exercises. In the beginning, we should choose some simple and easy materials that can attract students' interests. In this way, students' nervous and anxious emotions can be eased and they can slowly adapt to the listening class. Later, teachers can lead students to do some more difficult exercises to improve students' listening ability step by step. In listening class, teachers should create a relaxed and cheerful atmosphere, adopt various teaching methods and forms in the teaching process, stimulate students' passion for listening in a pleasant and relaxed atmosphere. Over time, teachers can help students build confidence in listening. At the same time, teachers should make students be aware of the difficult and gradual nature of acquiring a good listening ability, remind students to overcome the thought of "be eager to achieve" and do more listening practice, so that students can become more and more confident in doing listening practice.

Students tend to pay more attention to the single words rather than the whole sentences whenever they do listening exercises because they lack necessary listening skills. They also hold the idea that they should hear every single word clearly when doing listening practice and that only in this way can they fully understand the listening materials. Such a wrong idea leads to the consequence that students are unable to distinguish the major information from the minor one and when they encounter a new word, they will be afraid of it and cannot focus their attention on the following information. Furthermore, they will be very likely to give a wrong answer because of the previous missing word that caused their panic and fear. Meanwhile, due to the influence of the mother tongue, most of the students are always translating English into Chinese in their minds while doing listening practice. Therefore, teachers should train students to ignore those unfamiliar words in usual exercises, grasp key words, and be able to quickly record important words and information in a concise and understandable way. Secondly, students should be trained to develop the habit of predicting. In the course of listening practice, students should be instructed to make good use of the time of reading direction in the beginning so as to preview questions and options before the formal listening items. Then they can speculate on the listening content through the questions and options. Sometimes we can guess out the main idea after previewing that means we can get twice the result with half the effort. Teachers should also train students to develop the habit of taking notes anytime, learn to grasp key words and language markers in the process of listening, and write down key points and details, such as Numbers and names with the help of language markers, so as to help students strengthen their memory of the information they listen to and avoid forgetting the previous words while listening to the following words. Finally, teachers should combine the intensive listening materials with extensive listening materials. The intensive listening training helps to build 
students' confidence after getting the accurate answers. Students should repeat listening to the materials again and again until they understand every sentence fully . However, the materials should not be too difficult, but suitable for students' listening level. Extensive listening refers to listening to a wide range of materials in different styles from different sources. It's enough for Students to get the main idea of the content. In different periods, we should have different focuses and combine them while being appropriate, which can greatly improve students' listening ability.

\section{Conclusion}

The improvement of English listening ability is a difficult point in college English teaching. It is very important to help students realize that the training of listening is a long and complex process and that listening can not be improved greatly in a short period of time. Teachers should explore some new, various and flexible teaching modes to make students fall in love with English and enjoy listening to English. It has been proved that if students want to improve their listening, they must keep on practicing all the way. It takes a lot of determination and hard work for learners to gain a good listening ability. Students should insist on listening practice, then chances are that they can gain good listening ability and speak fluent English. On the other hand, teachers should communicate with their colleagues about their own experience of listening and develop new ways and methods to improve students' listening comprehension ability. Only through the joint efforts of teachers and students, can students' have a big improvement in listening.

\section{References}

[1] "College English curriculum requirements" (the ministry of education). 2007

[2] Anderson, A and T. Lynch. Listening [M]. London: Oxford University Press, 1988

[3] Jeremy Harmer. How to Teach English [M].Beijing: Foreign Language Teaching and Research Press, 2000

[4] Rod Ellis. Understanding Second Language Acquisition [M]. Shanghai Foreign Language Education Press, 1999

[5] Wu Xuehui. A Study on the Barriers in College Students' English Listening Comprehension [A]. College English Teaching and Research [C]. Beijing: Capital Normal University Press, 2000. 